\title{
Correction to: YSEC Yearbook of Socio-Economic Constitutions 2020
}

\author{
Steffen Hindelang and Andreas Moberg
}

\section{Correction to:}

\section{S. Hindelang, A. Moberg (eds.), YSEC Yearbook of Socio-Economic Constitutions 2020, YSEC Yearbook of Socio-Economic Constitutions 2020, https://doi.org/10.1007/978-3-030-43757-2}

The book was inadvertently published with an incorrect title for chapter 25 'Country Report on Hungary and Romania' whereas it should be 'Foreign Investment Screening in Hungary and Romania'.

In addition to this, the title of chapter 28, 'Comment on "In Search for an EU Competence to Establish an Investment Screening Mechanism and Restricting Effects Flowing from Fundamental Freedoms, Fundamental Rights, and Other EU Primary Law" should have read "Comment on "Exploring the Possibilities and Limits of the EU and Member States to Set Up an Investment Screening Mechanism in the Light of Union Law"'.

\footnotetext{
The updated online versions of the chapters can be found at https://doi.org/10.1007/16495_2020_25 https://doi.org/10.1007/16495_2020_28 